Krzysztof Konecki

Katedra Socjologii Organizacji i Zarządzania

Wydział Ekonomiczno-Socjologiczny

Uniwersytet Łódzki

\title{
SOCJOLOGIA POZA SOCJOLOGIĄ? POSTDYSCYPLINARNOŚĆ Z PERSPEKTYWY SOCJOLOGICZNEJ. DYLEMATY SOCJOLOGII W EPOCE PÓŹNEJ NOWOCZESNOŚCI
}

\section{Wprowadzenie}

Postdyscyplinarność jako pewien trend $\mathrm{w}$ badaniach i analizach naukowych powinna być zinterpretowana $\mathrm{w}$ świetle wielodyscyplinarności i transdyscyplinarności. Wielodyscyplinarność jest podejściem naukowym, które pozwala spojrzeć nam na dany temat czy problem badawczy $\mathrm{z}$ punktu widzenia wielu perspektyw. Pozwala lepiej zrozumieć nam określony temat/problem i wzmacnia walor wszechstronności interpretacyjnej dla danego projektu badawczego. Nie oznacza to, że różne dyscypliny są w stanie, w takim podejściu, przekroczyć swoje granice. Rozumienie zjawiska bezdomności z perspektywy wielodyscyplinarności (ekonomii, socjologii, psychologii, pracy socjalnej, antropologii kulturowej) nie oznacza integracji wiedzy i osiągnięcia ,jednego rodzaju” wnioskowania, w którym dyscypliny łączą się w jednym języku refleksji, diagnozy, prognozowania zjawiska i modeli interwencji społecznej.

Dla niektórych teoretyków nauki i współczesnego społeczeństwa wiedza, ekspertyza naukowa, generalnie ma charakter transgresywny. Przepływ wiedzy pomiędzy nauką a społeczeństwem jest czymś naturalnym. Transdycyplinarność byłaby zatem przekraczaniem granic dyscyplin (Gibbons i inni 1994). Wyłania się nowy wzorzec produkcji wiedzy, Mode 2 (Nowotny, Scott, Gibbons 2000: 11-33). Pierwszą cechą tego wzorca uprawiania nauki jest aplikacja. $Z$ tego też 
powodu problem do rozwiązania jest definiowany z punktu widzenia wielu różnych aktorów, których ta aplikacja dotyczy. Drugą cechą związaną z poprzednią jest wnoszenie różnorodnych umiejętności i ekspertyz w celu rozwiązania danego problemu. $Z$ tego też powodu wyłaniają się luźno powiązane ze sobą struktury organizacyjne. Trzecią cechą nowego wzorca produkcji wiedzy jest właśnie interesująca nas w tym momencie transdyscyplinarność. Przekraczanie granic dyscyplin pojawia się $w$ trakcie komunikacji i dyskusji, pojawiają się nowe pojęcia i narzędzia badawcze, które umożliwiają wytwarzanie nowej wiedzy w sposób ponaddyscyplinarny. W trakcie wytwarzania tej wiedzy często zaangażowani są różni interesariusze, organizacje pozarządowe oraz inne grupy organizujące się wokół określonych problemów do rozwiązania.

Innymi ważnymi cechami wzorca Mode 2 jest odpowiedzialność i kontrola jakości wytwarzania wiedzy. Trudno jest tutaj użyć kryteria oceny wiedzy pochodzące $\mathrm{z}$ jakiejś jednej dyscypliny, ponieważ występuje tutaj przekraczanie dyscyplin. Należałoby zatem tworzyć nowe kryteria oceny jakości wytwarzanej wiedzy.

Obecna relacja nauki i społeczeństwa została ukształtowana przez proces koewolucji tych dwóch dziedzin. Wzorzec pierwszy (Mode 1) wyraźnie oddzielał społeczeństwo od nauki. Wzorzec drugi kontekstualizuje naukę, co oznacza zwrot do społeczeństwa i ludzi oraz zadanie podstawowego pytania, ,gdzie jest miejsce dla człowieka w naszej wiedzy"? (Nowotny 2006). Dotyczy to nie tylko nauk społecznych, ale także genetyki, badań klinicznych, architektury, planowania przestrzeni miejskiej itp. Chodzi tutaj o nie tylko uwzględnianie protestów społecznych i krytyki społecznej czy wycofywania się ludzi z aktywności społecznej, ale o konceptualizację ich udziału w samych badaniach i wytwarzaniu wiedzy. W ten sposób można wytworzyć „silną społecznie wiedzę” (socially robust knowledge).

Ta ,silna społecznie wiedza” dotyczy udziału i zaangażowania nauki w zmianie społecznej, czego nauka wzorca pierwszego generalnie unikała. W naukach społecznych po wystąpieniu zwrotu lingwistycznego ${ }^{1}$ koncentrowano się na analizie

\footnotetext{
${ }^{1}$ Zwrot lingwistyczny objawiał się w koncentracji na analizie języka, wskazywaniu jego roli w konstruowaniu motywacji i działań ludzkich. Analizowano język, który tworzył wszelkie narracje o społeczeństwie. Istniejące dokumenty zapisane lub możliwe do zapisania w formie słownej, a także użycia samych technik i metod badan, jak wywiady socjologiczne, zapisy obserwacji, nawet eksperymenty naukowe są produkcją językową określonej wiedzy i wymagały z tej perspektywy namysłu i analizy, która na tym poziomie się zazwyczaj zatrzymywała. W socjologii reprezentantami tego typu perspektyw po zwrocie lingwistycznym była etnometodologia, analiza konwersacyjna z niej się wywodząca, różne rodzaje socjologicznie inspirowanych analiz dyskursu, socjolingwistyka.
} 
form i struktur językowych konstrukcji rzeczywistości. Socjologia nadal mogła zachować swoją integralność jako dyscyplina, choć metodologiczne podwaliny jej badań oparte na językowych materiałach zostały poważnie nadwyrężone przez krytykę ze strony socjologii zorientowanej lingwistycznie. Jednak obecnie niektórzy twierdzą, że należy wyjść poza epokę po zwrocie lingwistycznym, która dominowała w latach 70. i 80. XX w., gdy dyskutowano związek pomiędzy językiem a rzeczywistością, należy wyjść poza problematykę przedstawiania. Postmodernizm widział świat jako tekst $\mathrm{i}$ analizował $\mathrm{i}$ interpretował go jako tekst (Domańska 2007: 55-56). Tkwił on w epoce po zwrocie lingwistycznym, ponieważ sam się z niego wywodził.

Nowa humanistyka ma odzyskać podmiot; jest to podmiot performatywny, nie humanistyczny, jest on hybrydą, tworzy się w wydarzeniach, których nie jest widzem, ale inicjatorem i sprawcą (ibidem: 56). Występuje tutaj zwrot ku sprawczości i odejście od kontemplacyjności świata ${ }^{2}$. Tak widziany nowy podmiot domaga się wielodyscyplinarności analizy, która w efekcie łączy wiedzę z różnych dyscyplin i daje efekt antydyscyplinarny. Badacz tworzy tutaj wiedzę razem z ,badanymi” (podmiotami i przedmiotami). Nie chodzi tutaj o oddanie głosu milczącym mniejszościom, ale tworzenie ,ja performatywnego”, które poprzez odkrywający sposób zdobywania wiedzy i współpracę z innymi doprowadza do zmiany społecznej (ibidem: 60).

$\mathrm{Z}$ empirycznego punktu widzenia trudno byłoby nam zakwalifikować performatywizm jako nowy paradygmat, czyniący autentyczny zwrot w naukach społecznych i humanistycznych. Trudno zaobserwować ten trend w dominujących w Polsce badaniach społecznych. Performatywizm jawiłby się zatem jako równolegle istniejący obecnie nurt współczesnej humanistyki, równoległy do takich nurtów, jak postmodernizm, interakcjonizm, teoria krytyczna itd. To, co jest tutaj interesujące, to jego transdycyplinarność, ujęcie bowiem analiz np. interakcji ludzi z przedmiotami, zwierzętami, badania cyberprzestrzeni, badania nad płcią nie są możliwe z punktu widzenia jednej dyscypliny.

\footnotetext{
${ }^{2}$ Autorka twierdzi, że jest to projekt typowo marksowski i jest symbolem ,lewicowości” nowej humanistyki oraz efektem i elementem jego upolitycznienia (Domańska 2007: 56). Niekoniecznie tak musi być. Mogą być tutaj, według nas, inspiracje reformatorskie, nie rewolucyjne, nauka pozytywna miała na celu racjonalną zmianę świata. Można byłoby zapytać, co znaczy lewicowość dzisiaj? Wielu badawczy nie identyfikujący się z lewicowością zajmuje się związkami i interakcjami ludzi ze zwierzętami i przyrodą i światem materialnym (w tym przedmiotami). Zajmowanie się „hybrydami”, sprawczością, pragmatycznym stosowaniem wyników badań w realnym świecie, jednoczesnym uczestnictwem w świecie „badanym”, a nawet zaangażowania w zmianę społeczną nie musi oznaczać „lewicowości”, cokolwiek ona znaczy.
} 


\section{Znaczenie pojęcia „dyscypliny naukowej” - różne ujęcia: strukturalne, działaniowe i interakcjonistyczne}

Dyscypliny naukowe można różnie rozumieć. Z punktu widzenia nauk bibliotekoznawczych (Library and Information Science, LIS) dyscypliny są rozumiane jako pragmatyczne narzędzia identyfikowania i organizowania informacji i wiedzy (Nyström 2007: 124).

Trzeba podkreślić także historyczny wymiar kształtowania się dyscyplin naukowych. Rozproszona wiedza w wieku XVIII zaczęła być integrowana i dzielona na wiedzę naukową i nienaukową, a ta ostatnia na obszary wiedzy. Micheal Foucault nadmienia, że wystąpiły cztery procesy, które pozwoliły uformować z rozproszonej, poliformicznej wiedzy naukowe dyscypliny:

- eliminowanie lub dyskwalifikowanie nienaukowej wiedzy;

- normalizowanie tych typów wiedzy, by móc dopasowywać je do siebie i umożliwić komunikację pomiędzy nimi;

- hierarchiczna klasyfikacja wiedzy pozwalająca łączyć różne poziomy wiedzy;

- piramidalna centralizacja wiedzy, która umożliwia kontrolowanie wszystkich tych rodzajów wiedzy (Foucault 2003: 179f, cyt. za Nyström, 2007: 126).

Wiedza jest dyscyplinowana. Zatem dyscyplina socjologii może być także potraktowana jako wynik tych procesów. Dyscyplinowanie wiedzy o społeczeństwie polegało na gromadzeniu różnych rodzajów wiedzy (historii, filozofii społecznej, wiedzy o egzotycznych ludach, etyki, danych demograficznych) pod jedną etykietą socjologii. Tak skumulowana wiedza podlegająca regułom gromadzenia i weryfikacji naukowej była łatwiejsza do kontrolowania.

\section{Ujęcie strukturalne}

Dyscyplina naukowa może być utożsamiona z wykształceniem się instytucjonalnej bazy jej uprawiania. Pojawia się wtedy struktura organizacyjna i wykształca się w powiązaniu z nią określony segment struktury społecznej, który wypełnia pozycje w określonych organizacjach. Pozycje te opisane są za pomocą określonych definicji działalności naukowej, które oddają istotę dyscypliny (centralne kategorie definicyjne dyscypliny) i jej obrzeża często wchodzące w obszar innych definicji działań naukowych (kategorie określające subdyscypliny). Struktura instytucjonalna, o której jest tutaj mowa, to zazwyczaj obszar 
społeczny, który potocznie jest nazywany Akademią. Ze strukturalnego punktu widzenia konkretnie stanowiłyby ją instytucje zwane uczelniami wyższymi oraz państwowe i prywatne instytucje zajmujące się tym, co określa się nauką, a więc taką dziedziną działalności ludzkiej, która w sposób systematyczny i intersubiektywnie i empirycznie sprawdzalny i dający się weryfikować wytwarza wiedzę oraz kumuluje ją, przestrzegając ogólnie przyjętych rygorów naukowości. Niezależność dyscypliny związana jest z tworzeniem bazy instytucjonalnej dla jej wyodrębniania w strukturach akademickich. Chodzi tutaj o tworzenie instytutów, katedr, czasopism i innych tego typu struktur (zob. Kojder 2012: 16-17).

Strukturalne ujęcie umieszcza niejako naukę i występujące w niej dyscypliny naukowe w szerszym systemie społecznym. Struktury akademickie i badawcze pozaakademickie są powiązane sieciami różnych interesów z instytucjami politycznymi, gospodarczymi, religijnymi itd. Niezależność Akademii jest w świecie zachodnim postulatem (wzorcem), który w określonych warunkach społecznych jest sprawdzany i weryfikowany.

Finansowanie określonych dyscyplin naukowych ma olbrzymi wpływ na ich znaczenie instytucjonalne i prestiż. Kryteria finansowania nauki przez różne instytucje sponsorskie decydują nie tylko o tym, jakie tematy badawcze będą priorytetem $\mathrm{w}$ danym czasie, ale również jakie dyscypliny naukowe i subdyscypliny zyskają, a jakie stracą. Decyduje to także o położeniu, żywotności instytucji naukowych zbudowanych na dyscyplinarnym podziale. Pewne instytuty naukowe, czy uczelnie mogą stracić na znaczeniu, a nawet zniknąć, jeśli tematy badawcze i związane $\mathrm{z}$ nimi dyscypliny zostały niedocenione przez decydentów finansowania nauki. Uzależnienie dyscyplinarności od uwarunkowań strukturalnych daje, $\mathrm{z}$ jednej strony, względną stabilność instytucjonalną dyscyplinom, a zajmującym pozycje w tych instytucjach stabilność zatrudnienia i rozwoju karier, a $\mathrm{z}$ drugiej strony pewne zamknięcie mentalne związane z instytucjonalnymi definicjami dyscypliny i dyscyplinarności.

Generalnie granice dyscyplin są wyraźnie określone i strzeżone przez ich strażników. Strażnikami granic są zwykle osoby na najwyższych pozycjach organizacyjnych $w$ danej dyscyplinie zdefiniowanej instytucjonalnie. Mają one także często wielu sojuszników w innych strukturach, którzy czerpią wiedzę naukową i wykorzystują ją w swojej pracy (zob. Merton 1965). Strażnicy, broniąc dyscypliny, bronią swoich pozycji i przywilejów organizacyjnych związanych $\mathrm{z}$ daną pozycją oraz $\mathrm{z}$ definiowaniem wiedzy naukowej w swojej dyscyplinie i z wytwarzaniem oraz dystrybucją oraz redystrybucją wiedzy uzyskanej w czasie teraźniejszym oraz przeszłym. 


\section{Ujęcie działaniowe/interakcjonistyczne}

Ujęcie działaniowe dotyczyłoby definiowania dyscypliny przez pryzmat działań, które podejmuje się w ramach określonej tematycznie działalności naukowej. Działania wyznaczane są poprzez cele i środki użyte do osiągania ich w danych warunkach, które mogą być sprzyjające i/lub przeszkadzające.

Zastosowanie określonego środka (metody), by osiągnąć dany cel badawczy/analityczny jest działaniem. Użycie eksperymentu jest działaniem, użycie wywiadu jest działaniem, użycie obserwacji jest działaniem. Wszystkie one są podejmowane w określonych prewarunkach $\mathrm{i}$ warunkach, mają swoją temporalną dynamikę, są podtrzymywane i powtarzalne $\mathrm{w}$ czasie lub wygaszane przez kontrdziałania i działania innowacyjne.

Prewarunki określają możliwości pełnego i prawidłowego zastosowania określonych metod, by osiągnąć założone cele, skonstruowane w trakcie prekonceptualizacji. Prewarunki są to określone środki materialne umożliwiające podjęcie badania/analizy. Natomiast warunki działania dotyczą przestrzenno-czasowych kontekstów realizacji działań naukowych (badań i/lub analiz) i tutaj znajdują się materialne oraz historyczne podstawy dla definiowania, czym jest działanie naukowe i czym jest efektywne działanie naukowe.

Inny rodzaj działań to działania organizacyjne, które służą obronie, trwaniu i rozwojowi dyscypliny (i często subdyscyplin, choć czasami obrona jakiejś kontrowersyjnej subdyscypliny może zaszkodzić wizerunkowi dyscypliny). Działania organizacyjne dotyczą zdobywania środków materialnych dla podtrzymywania i rozwoju dyscypliny. Zaplecze materialne dotyczy zdobywania środków finansowych, budynków, tworzenia instytucji, tworzenia pozycji i etatów. Liczba zatrudnionych w instytucjach definiujących się poprzez dyscyplinę świadczy o sile danej dyscypliny w świecie akademickim.

Inny rodzaj działań to te promujące daną dyscyplinę, podtrzymujące jej naukowy wizerunek. Szczególnie dotyczy to takich dyscyplin, co do których często są wątpliwości, czy są one naukowe, jak: psychologia, socjologia, nauki o komunikowaniu itd.

Te wszystkie działania składają się na społeczną konstrukcję dyscypliny naukowej. Konstrukcja dyscypliny to nie tylko definiowanie, czym jest dana dyscyplina, ale także inne działania związane z ciągłym potwierdzaniem jej założeń i odrębności od innych dyscyplin. „Dyscyplina naukowa” jest działaniem połączonym wielu działań cząstkowych, o których zaledwie wspomnieliśmy powyżej. Łączą się tutaj, m.in., działania administratorów nauki, propagatorów 
nauki z działaniami samych naukowców prowadzących swe badania i analizy. Zachodzą tutaj zatem interakcje, które wytwarzają połączone działania różnych aktorów. Działania te mają charakter powtarzalny, wymagają ciągle nowych uzgodnień i uściślania definicji celów. Tematy badawcze i tematy konferencji są często próbą sprawdzania granic danej dyscypliny. Wychodzenie poza dyscyplinę jest przedsięwzięciem ciekawym, acz niebezpiecznym dla młodych adeptów nauki, którzy muszą się zdefiniować, w której wiązce działań powiązanych ze sobą chcą się ulokować. Ma to znaczenie dla ich kariery naukowej. Wielodyscyplinarność i transdyscyplinarność (Kita, Sławska 2012; Domańska 2011) może być przygodą intelektualną przede wszystkim dla uznanych i mocno osadzonych w swojej dyscyplinie naukowców, którzy osiągnęli już szczyt kariery naukowej i mogą sobie pozwolić na innowacyjne działania, które wymagają wyjścia poza własną dyscyplinę (por. Fleck 1935/1986). Takie są też przedsięwzięcia (działania), które dotyczą transdycyplinarności (gdzieś tutaj znika dyscyplina, przesuwamy się bowiem w swym oglądzie kultury i rzeczywistości społecznej ponad granicami dyscyplin) i wielodyscyplinarności, gdzie dyscyplinarność jest zachowana, ale pojawia się konieczność uczenia się metod i podstaw innych dyscyplin. Niezbędne jest to chociażby do interpretacji wyników badań z innych dyscyplin naukowych. Może to być początkiem wychodzenia poza dyscyplinarne ujęcie nauki, ale nie musi.

Jakie działania podtrzymujące dyscyplinarność tutaj mają miejsce? Jednym z tych, które ogniskuje i pokazuje jednocześnie istotę działania połączonego, jest konferencja naukowa. Główną częścią są działania sprawozdawcze. Skupiają się tutaj sprawozdania z działań badawczych, występują działania promocyjne, a także publikacyjne i dystrybuujące efekty działań badawczych (książki, artykuły, prezentacja patentów). Konferencja wielodyscyplinarna może dać zaczątek działaniom transdycyplinarnym, kiedy przekraczamy granice dyscyplin i uczymy się nowych podejść z innych dyscyplin, by je później użyć już bez powiązania z dyscypliną, a raczej z problemem, który mamy do zbadania. To właśnie wychodzenie od problemu do rozwiązania pozwolić może wyjść poza granice dyscypliny. To, co istotne, to praktyczność i aplikowalność wiedzy, a to odbywa się w samym działaniu badacza społecznego i osób, których badanie dotyczy. Aplikowalność wiedzy, jako konkretne i praktyczne działanie, jest tutaj krokiem zdecydowanie wykraczającym poza kanony uprawiania nauki społecznej akceptowanej dziś w Akademii. Generalnie przyjmuje się, że np. socjolog powinien obserwować i stawiać diagnozy społeczne, co najwyżej być w roli eksperta (zob. Sztompka 2012: 12-13). Nie powinien podejmować działań społecznych, a jego badania i analizy powinny mieć charakter „,neutralny” ${ }^{3}$. Wiara w „,neutralność” nauki

3 „Socjologowie mają prawo do wartościowania, kierowania się poglądami etycznymi, otwartego wypowiadania sądów oceniających w dwóch etapach swojej działalności: przy wyborze 
społecznej i humanistyki jest silnie zakorzeniona w Akademii, choć bliższa analiza socjologii nauki problemu „neutralności” pokazuje, że jest to postulat również mający charakter ideologiczny, a jego stosowalność w realnym świecie nauk społecznych i humanistycznych ma charakter ograniczony.

\section{Obrona dyscyplinarności - to obrona granic społecznego świata socjologii}

W ujęciu działaniowym Akademię można potraktować jako świat społeczny. Świat społeczny jest pewną formą asocjacji społecznej opartą na wspólnych zainteresowaniach i podjęciu jakiegoś działania podstawowego, które wykonują jednostki i to definiuje ich przynależność do tego świata.

Świat posiada wyróżniające go działanie podstawowe, które wiąże się z innymi działaniami pomocniczymi, wspomagającymi główną działalność społecznego świata. To działanie także pozwala określać jednostkom ich identyfikacje i tożsamości.

Pojęcie świata społecznego zostało wypracowane w socjologii interakcjonis tycznej przez Anselma Straussa $(1978,1982)$ i jego kontynuatorów (Becker 1982; Star, Griesmer 1989; Clarke 1991, zob. także Kacperczyk, 2005). Świat społeczny, jak stwierdziliśmy, ogniskuje się wokół pewnego podstawowego działania, które go wyodrębnia. Można wyróżnić wiele społecznych światów, np. świat badaczy jakościowych, świat praktykowania jogi, świat wspinaczki wysokogórskiej, świat tańca towarzyskiego, świat zbierania znaczków, świat medycyny nie konwencjonalnej, świat podróżowania turystycznego, świat socjologii, świat antropologii, świat psychologii i tym podobne. Świat posiada wyróżniające go działanie podstawowe, które wiąże się z innymi działaniami pomocniczymi wspomagającymi główną działalność społecznego świata. Światy te z kolei mogą dzielić się na subświaty, które bardziej specjalizują się w danym działaniu podstawowym i wykonują jego część. Występuje tutaj zatem podział pracy.

Powstają też areny sporu: kto jest autentycznym członkiem danego świata, jakie są jego granice, jakie są uzasadnienia dla jego istnienia (tzw. legitymizacja), i tym podobne. Czasami pojawia się obiekt graniczny, który jest elementem, wokół którego toczy się spór ${ }^{4}$. Czy nowy subświat ma wystarczającą legitymizację do istnienia i działania?

problemów badawczych i przy komentowaniu wyników, natomiast $\mathrm{w}$ procesie badań, czyli osiągania wyników, muszą zachować całkowitą neutralność i dystans” (Sztompka 2012: 12).

${ }^{4}$ Patrząc z punktu widzenia teorii „uznania i uspołecznienia“ Axela Honnetha (2012), można byłoby stwierdzić, że procesy społecznych światów (walka o legitymizację, teoretyczne uzasadnienia ich istnienia, areny i spory o obiekty graniczne itp.) są ,walką o uznanie” w społeczeństwie, gdzie 
Świat społeczny dzieli się zatem na subświaty, tak też można byłoby skategoryzować działalność świata akademickiego, gdzie uprawianie nauki odbywa się w określonych dyscyplinach, w ramach których powstają subdyscypliny. Choć dla czystości wywodu nazywać będziemy dyscypliny światami społecznymi, a nie subświatami.

Określony świat posiada miejsca, gdzie działanie może być realizowane. Są to w przypadku naszej analizy ośrodki naukowe, instytuty socjologii. Świat posiada także technologię, czasami innowacyjną (oprzyrządowanie i programy komputerowe, programy obliczeniowe i archiwizacji oraz katalogowania danych, programy obróbki filmów i fotografii), która pozwala wykroić dla danego świata przestrzeń zarówno symboliczną, jak i przestrzeń fizyczną. W społecznym świecie mamy zwykle podział pracy - jedni zajmują się uzasadnianiem istnienia świata (legitymizacją i teoretyzowaniem oraz działaniami public relations). Czynią to w imieniu świata wielcy uczeni (również w mediach), dyrektorzy instytutów, wydziałów, Komitet Socjologii PAN, Polskie Towarzystwo Socjologiczne itp. Inni poszukują nowych miejsc dla działania, zajmują się dydaktyką i nauczaniem technicznych umiejętności przeprowadzania badań itd. Niektórzy reprezentanci tego świata wykonują wiele z tych działań sami. Istnieje także wiele działań towarzyszących, jak obrona, atak, w tym celu tworzy się stowarzyszenia (Polskie Towarzystwo Socjologiczne), co wspomaga realizację działania podstawowego, czyli analiz i badań socjologicznych (w sprawie teorii światów społecznych patrz Strauss 1978 oraz bardzo dokładne i szczegółowe opracowanie Kacperczyk 2005).

Oprócz tego powstają też areny sporu:

- kto jest autentycznym członkiem tego świata, czyli kto jest ,prawdziwym" socjologiem; czy wystarcza wykształcenie socjologiczne, czy też praca w charakterze socjologa, czy też może istotne jest tutaj członkostwo stowarzyszone w PTS?

- jakie są granice świata, gdzie przebiegają?

- jakie są uzasadnienia dla istnienia tego świata (tzw. legitymizacja), społecznie akceptowalne motywy i tym podobne.

Czasami pojawia się obiekt graniczny, czyli element, wokół którego toczy się spór. Takimi obiektami granicznymi mogą być „,prawomocne” (lub nie) dla danej dyscypliny tematy/problemy badawcze. Być może $\mathbf{z}$ takim obiektem granicznym mamy do czynienia w przypadku sporu o postdyscyplinarność? Byś może jest tutaj spór o metodę/y socjologiczną/e? Czy nie-socjolog może

system aksjonormatywny często jest zamknięty na innowacje i na wyłaniające się nowe grupy interesu. 
stosować kompetentnie i odpowiedzialnie socjologiczne metody badawcze? Jest to bardzo drażliwa kwestia, tym obiektem sporu bowiem staje się sama socjologia i jej integralność. Przekraczanie przez metody badawcze granic świata socjologii czyni te granice porowatymi, przepuszczalnymi także w drugą stronę i dotyczy to nie tylko przepływu metod badawczych, ale także perspektyw teoretycznych. Dyscypliny zmieniają się, jeśli chodzi o poszerzanie przedmiotu badań i zmieniają się także ich granice ${ }^{5}$.

Teoria światów społecznych pokazuje zatem, że dyscypliny walczą o swoją integralność budując też tradycję (np. poprzez konferencje poświęcone wybitnym socjologom i założycielom socjologii w różnych ośrodkach, lub konferencje nobilitujące nowych ,klasyków”) by legitymizować aktualne działania. Pamiętajmy, że zaangażowane są tutaj także tożsamości i identyfikacje ,ja - socjolog”. Tożsamości te dają motywację do działań mających na celu utrzymanie pozycji socjologów w świecie instytucjonalnym, a więc ich pracy, dochodów i ścieżek karier i w konsekwencji ich pozycji w strukturze społecznej danego społeczeństwa. Pojawia się często strach, że postdyscyplinarne badania pokażą niedostatki orientacji dyscyplinarnych i bliski kres dyscypliny, z którą związana jest tożsamość uczonego i jego pozycja instytucjonalna a także społeczna.

\section{Wskaźniki postdyscyplinarności - podsumowanie}

Jakie zatem można przedstawić wskaźniki postdyscyplinarności? Poniżej na podstawie naszych analiz przedstawiamy trzy podstawowe wskaźniki: aplikowalność, nowe trendy epistemologiczne, nowe metody badawcze.

1. Aplikowalność w kontekście współpracy z uczestnikami badania. Coraz większa potrzeba aplikowalności wiedzy powoduje, że wzorzec drugi wytwarzania wiedzy skonceptualizowany przez Helgę Nowotny może stać się zarazem wzorem działań naukowych i społecznych. Model ten może być zatem wskaźnikiem postdyscyplinarności, pojawia się bowiem obecnie konieczność badania określonych problemów z uwzględnieniem potrzeb ludzi, ich poglądów, zaufania i ich postaw w stosunku do nauki (Nowotny 2006: 4). Konkretyzacją

\footnotetext{
${ }^{5}$ Areny ciągle wyłaniają się w świecie nauki, dynamizując przemiany dyscyplinarne: „Podział na dyscypliny nie ukształtował się 300 lub więcej lat temu, lecz jest znacznie świeższej daty. Trudno więc zakładać, że jest to podział trwały. Niektóre domeny »zagarnięte« przez daną dyscyplinę próbują uzyskać autonomię, inne rozpływają się w jej głównym nurcie, a jeszcze innym udało się zmienić dyscyplinową przynależność” (Kojder 2012: 29).
} 
tego wskaźnika mogą być sondaże deliberatywne, a szerzej demokracja deliberatywna czy sądy obywatelskie (Krzewińska 2012). Sondaże deliberatywne mogą być pierwszym krokiem do ,skonceptualizowania ludzi” w projektach badawczych, a także w projektach różnego rodzaju zmian, np. w przestrzeni miejskiej, architekturze, ale także w działaniach i projektach dotyczących ochrony środowiska i zrównoważonego rozwoju.

2. Epistemologia. Inny impuls dla ,postdyscyplinarności” to zmiany w rozumieniu prawdy w nauce. $W$ tym przypadku mamy na myśli inspiracje płynące z pragmatyzmu społecznego (Rorty 1982; Baert 2003, 2005). Niemożliwe jest wykonanie badania z neutralnego punktu widzenia (Rorty 1982, 1999). Nie ma twierdzeń ogólnych prawdziwych zawsze i wszędzie, wszystko zależy od warunków, w których są wypowiadane oraz od sytuacji. W stwierdzeniach o rzeczywistości nie ma nic ogólnego, co dotyczyłoby wszystkich podobnych zdarzeń (stwierdzeń o tych zdarzeniach). Określone zdania są słuszne w określonych warunkach (sytuacji). Nic nie wskazuje, że są one słuszne zawsze i wszędzie. Prawda, według pragmatyzmu, jest nazwą dla własności, którą posiadają wszystkie stwierdzenia o prawdzie (Rorty 1982: XIII). Prawda i dobroć są własnościami zdań lub działań, lub sytuacji (ibidem: XIV). Zatem jest tutaj pewne nawiązanie do lingwistycznego zwrotu w humanistyce, jednak zwrot ten jest naturalnym poprzednikiem zwrotu performatywnego (który jest z nim związany) akcentującego działanie i zmianę społeczną (patrz następny paragraf, por. także Rorty 1999 oraz Nyström 2007).

2a. Performatywność. Świat w naukach społecznych i naukach o kulturze jest w koncepcji performatywności nauk rozumiany jako świat działań, w których uczestniczą naukowcy.

Niektórzy analitycy współczesnej kultury i nauki uważają, iż obecnie nastąpił zwrot performatywny. Termin ten został powiązany z pojęciem performansu. „W kontekście zwrotu performatywnego performance w sensie wąskim to wykonanie na żywo w obecności »widowni «pewnego działania mającego charakter teatralnego aktu, a w sensie szerokim - codzienna praktyka życia społecznego przejawiająca się w rytuałach, demonstracjach, paradach, festiwalach itp.; performatywność natomiast rozumiana jest jako przeświadczenie, że język nie tylko przedstawia rzeczywistość, lecz także powoduje w niej zmiany, a ponadto, że pewne zjawiska istnieją tylko w akcie ich wykonywania i że muszą być powtarzane, by zaistnieć" (Domańska 2007: 49). W koncepcji performatywności istnieją także wpływy antropologicznej analizy rytuałów. Pojawia się tutaj nowa dziedzina interdyscyplinarnych akademickich badań tzw. performance studies, A także połączenie nauki i sztuki. Powstają nowe hybrydy łączące sztukę z profesjonalną wiedzą. „Prezentacja zdjęć (Power Point) to nie tylko ilustracja wystąpień, lecz treść sama w sobie" (ibidem: 51). Interdyscyplinarność jest już tutaj przekraczana i można powiedzieć, że mamy do czynienia z antydyscyplinarnością. 
Autorka wymienia cechy zwrotu performatywnego: „nastawienie na sprawczość i zmiany wywoływane w rzeczywistości, rozszerzenie rozumienia sprawczości na byty nie-ludzkie (posthumanistyczne oblicze idiomu performatywnego), interdyscyplinarność czy antydyscyplinarność badań oraz wyjście poza metaforę świata rozumianego jako tekst $\mathrm{w}$ kierunku metafory rozumienia świata jako wielości performatywnych działań i jako performance'u, w którym się uczestniczy" (ibidem: 52). Celem nauki nie jest kontemplacja i refleksja nad światem i człowiekiem, a raczej bunt wobec świata. Zwrot performatywny ma charakter posthumanistyczny, gdzie sprawczość przypisuje się nie tylko ludzkim, ale i bytom nieludzkim (zwierzętom, obiektom świata materialnego) (ibidem: 52-53).

Widać z tego wyraźnie, że zwrot performatywny wskazuje na przenikalność granic dyscyplin i wędrowanie metod/sposobów badania i prezentacji. Performance może być stosowany jako metoda w różnych postaciach w sztuce, socjologii, pedagogice, antropologii itd. Może to być np. postać etnografii performatywnej zastosowanej do kształcenia doradców pracy (Siarkiewicz, Trębińska-Szumigraj; Zielińska-Pękal 2012).

3. Metody badawcze. Wskaźnikiem na postdyscyplinarne tendencje w metodologii nauk społecznych może być stosowanie metody ,autoetnografii”. Autoetnografia powstaje dzięki połączeniu wielu metod badawczych, podejść teoretycznych i gatunków produkcji kulturowej. Etnografia jest tu wiązana z autobiografią. Mamy tutaj także łączenie etnografii, antropologii kultury (poznawanie wzorów kulturowych poprzez autoetnografię) - socjologii, performing art, literatury, analizy literackiej, epistemologii czy nawet ,filozofii poznania". Wszystko to skorelowane jest $\mathrm{z}$ autentycznym działaniem badacza $\mathrm{w}$ realnym świecie, w którym uczestniczy i który bada oraz go zmienia. „Autoetnografia jest perspektywą badania i sposobem pisania, która poszukuje systematycznej analizy i opisu osobistego doświadczenia (auto), by zrozumieć kulturowe doświadczenia (ethno)... Podejście to krytykuje kanoniczne sposoby prowadzenia badań i reprezentowania innych... oraz traktuje badanie jako polityczne, społecznie usprawiedliwione i społecznie świadome działanie... Badacze używają zasad autobiografii, by wykonać i opisać autoetnografię. Autoetnografia jako metoda jest zarówno procesem i produktem określonego działania" (Ellis, Adams and Bochner 2010: 1; także Wall 2008; por. także odmienne podejście do autoetnografii, bardziej zakorzenione w realistycznej etnografii, Anderson 2006, Kacperczyk 2012).

Innym możliwym do przyjęcia wskaźnikiem postdyscyplinarności byłoby używanie metody krytycznej analizy dyskursu (KAD). Następuje tutaj łączenie lingwistyki i nauk społecznych (Duszak, Fairclough 2008) oraz badań nad 
mediami (Wodak, Krzyżanowski 2008; por. także Flick 2007). Ważny jest tutaj przedmiot badań - dyskurs - i od skupienia analitycznej uwagi na dyskursie rozpoczyna się badanie. Nie koncentrujemy się tutaj na granicach dyscypliny, by analizę wykonać dokładnie z jej założeniami (por. Stubbe i inni 2013, zob. także Rancew-Sikora 2013).

Zacytujmy tutaj van Dijka odnośnie do oceny KAD: „krytyczna analiza dyskursu nie jest prosta. Moim zdaniem jest to jedno z najcięższych zadań w dyscyplinie. Wymaga prawdziwego wielodyscyplinarnego przygotowania i wyjaśniania zawiłych relacji między tekstem, mową, poznaniem społecznym, władzą, społeczeństwem i kulturą" (1998: 370; cyt. za Stubbe i inni 2013: 140).

Każda analiza dyskursu interakcyjnych aktów komunikacji wymaga analizy zachowań niewerbalnych. Przykładem jest interakcyjna lingwistyka (Gumperz) (a więc należy użyć tutaj wiedzy z zakresu psychologii), często do interpretacji parawerbalnych zachowań (zdenerwowanie) niezbędna jest znajomość kontekstu interakcyjnego (a więc należy zastosować etnografię miejsca). Wskazówki kontekstualizacyjne często są kwestią wyboru na poziomie leksykalno-gramatycznym (a więc niezbędna jest tutaj analiza lingwistyczna/językowa). Wszystko to wskazuje na konieczność współpracy pomiędzy różnymi dyscyplinami naukowymi i ostatecznie wyjście poza nie.

Choć należy stwierdzić, że oczywiście nadal istnieje obrona dyscyplin w ramach analizy dyskursów, np. psychologia dyskursywna nadal jest psychologią, ale już teoria grzeczności bardziej koncentruje się na problemie ochrony twarzy niż na apriorycznym tworzeniu granic dyscyplinarnych przyjmowaniu założeń. Choć należy jednak stwierdzić, że interakcyjna socjolingwistyka jest bardziej interdyscyplinarna niż postdyscyplinarna. (por. Stubbe i inni 2013).

Analizy wizualne, zwane często visual studies, to także nasza propozycja na wskaźnik postdyscyplinarności, który proponujemy do ewentualnego rozpatrzenia w przyszłych analizach i badaniach (zob. Olechnicki 2003, Pink 2003, Sztompka 2005). Tutaj także występuje zjawisko przekraczania dyscyplin, gdzie spotykają się socjologia wizualna z antropologią wizualną, architektura i urbanistyka z psychologią poznawczą i socjologią miasta i przestrzeni. Stosowana w badaniach jest fotografia (często jest używana także fotografia artystyczna), nagrania audiowideo, filmy socjologiczne $\mathrm{i}$ antropologiczne, performance oraz hipermedialne analizy i prezentacje. Tych przecięć pomiędzy różnymi dyscyplinami i subdyscyplinami (a tym samym światami społecznymi, które dane dyscypliny obejmują) oraz gatunkami prezentacji produktów kulturowych jest tutaj wiele.

Używanie metodologii teorii ugruntowanej również jest tutaj wskaźnikiem postdyscyplinarności. Ta analiza danych, ale także będąca pewną wersją metodologii nauk społecznych, sugeruje, byśmy wychodzili w naszych analizach danych 
empirycznych od ogólnie zarysowanego tematu lub problemu badawczego. Stosując procedury tej metodologii, nie zaczynamy naszych analiz od wyraźnie skonceptualizowanych kategorii i hipotez. Kategorie analityczne i hipotezy pojawiają się w trakcie analiz, gdy stosujemy procedury kodowania teoretycznego i analizy porównawczej oraz teoretycznego pobierania próbek (Glaser, Strauss 2009; Charmaz 2009; Konecki 2000). To, co jest istotne, to temat badawczy, a następnie kategoria teoretyczna (lub kilka kategorii teoretycznych), wokół której koncentrujemy się, zbierając różnego rodzaju dane, by konstruować nowe własności kategorii i budować hipotezy dotyczące przebiegu zjawiska/procesu. Metodologia ta nie jest przypisana do jednej dyscypliny ani nauk społecznych, ani nauk humanistycznych.

\section{Konkluzje}

Do interdyscyplinarności w socjologii zachęcają znani polscy socjologowie. Granice socjologii stają się mniej ważne, gdy istotne staje się poprawne zbadanie jakiegoś problemu:

„Socjologia nie może izolować się, odgradzać murem od innych nauk o człowieku, przeciwnie, musi korzystać z ich osiągnięć i ofiarowywać im własne.

Świat nie dzieli się na wydziały uniwersyteckie. Granice między dyscyplinami zbudowane przez kumulującą się, często przypadkową praktykę administracyjną od XIX w. muszą być przekraczane, jeśli wymaga tego problem badawczy...

Najwyższy stopień integracji to transdyscyplinarność, czyli połączenie różnych dyscyplin w jedną naukę o człowieku - owej, jak pisał Pascal - trzcinie myślącej - która jest zarazem organizmem i osobowością, indywidualnością i malutkim fragmencikiem społeczeństwa, istotą cielesną i duchową. To jest jednak, jak się wydaje, sprawa dalekiej przyszłości” (Sztompka 2012: 13).

Transdycyplinarność i postdyscyplinarność często spotyka się z dużym oporem ze strony tzw. Akademii i współczesnych uniwersytetów. Jest to związane $\mathrm{z}$ licznymi warunkami strukturalnymi i mentalnymi, w jakich działają administratorzy nauki i sami naukowcy. Uniwersytety mają hierarchiczne struktury broniące dyscyplinarności (katedry, zakłady, stopnie naukowe osiągane w ramach dyscyplin). Ich konserwatyzm i obrona własnych struktur i tożsamości ogranicza produkcję nowej, innowacyjnej wiedzy społecznej, a przede wszystkim wiedzy aplikacyjnej. Innowacje powstają na styku nauki i użytkowników (patrz osiągnięcia informatyki, i inżynierii środowiskowej). Ponadto innowacje są możliwe przy transgresywności naszej wiedzy, a więc $\mathrm{w}$ nauce poprzez zastosowanie 
zasady transdycyplinarności jako pierwszego kroku do zbudowania pola dla postdyscyplinarności, którą ostatecznie rozumiemy jako pole, gdzie spotykają się przedstawiciele już nie dyscyplin, ale zdyscyplinowanych umysłów naukowych, konstruujące nowe pomysły narzędziowe i konceptualne, nowe kryteria ewaluacji jakości wniosków naukowych poprzez dyskusję oraz praktyczne uwzględnienie ludzi i ich perspektyw pochodzących z różnych światów społecznych, dla których rozwiązania problemów pracują.

Wyjście poza dyscypliny i uwzględnienie ludzi w badaniach naukowych jest innowacyjne i buduje dużą moc aplikacyjną wniosków badawczych. Obserwując rzeczywistość i uwarunkowania instytucjonalne Akademii, dyscypliny nie znikną w najbliższej przyszłości, ale sposób myślenia o ich użyciu w rozwiązywanie konkretnych problemów zmienia się już dzisiaj (Afeltowicz, Pietrowicz 2013). Myślimy coraz częściej o aplikowalności naszej wiedzy w powiązaniu z udziałem zainteresowanych osób, reprezentantów społeczności czy nawet szerszych zbiorowości. Nauka przestaje być własnością ekspertów, naukowców zamkniętych w murach Akademii, wchodzi ona w system komunikowania ze społeczeństwem o niespotykanej do tej pory natężeniu tego komunikowania. Członkowie społeczności nie tylko chcą wiedzieć, co wynika z określonych badań naukowych, ale jakie ma to mieć dla nich bezpośrednio konsekwencje i czy ich głos został w tych badaniach uwzględniony.

Niektórzy badacze wskazują na konieczność nawiązywania do podstaw dyscyplin. Sarah Pink twierdzi, że częsta krytyka innych podejść np. w badaniach wizualnych nie jest zasadna, osoby bowiem podejmujące krytykę z pozycji interdyscyplinarnych nie znają często krytykowanych dyscyplin, ich historii i nie mogą skontekstualizować czyichś badań i wniosków (Pink 2003: 188). Zarzucanie komuś braku refleksyjności nie jest słuszne, ponieważ refleksyjność może być różnie rozumiana i realizowana w poszczególnych dyscyplinach. Ponadto trzeba tutaj uwzględnić wymiar historyczny refleksyjności (ibidem). Inna refleksyjność obowiązywała w ,stadium” przed przewrotem lingwistycznym, a inna po tym przewrocie. Obecnie w różnych analizach koncentrujących się na konkretnych tematach używa się wiedzy z różnych dyscyplin. Współczesna refleksyjność jest co najmniej transdycyplinarna, jeśli nie postdyscyplinarna (por. Nyström 2007). Być może będziemy mówić o nauce humanistyczno-społecznej/naukach społecznych, a nie o poszczególnych dyscyplinach. Granice pomiędzy naukami społecznymi i humanistycznymi są niezwykle obecnie porowate i przenikalne: „Micheal Foucault, z jego zainteresowaniami lingwistycznym i dyskursywnym formowaniem władzy, był najczęściej cytowanym autorem w dyscyplinie historii, literatury, ogólnej nauki humanistycznej i antropologii i drugim najczęściej cytowanym autorem w naukach społecznych" (ibidem: 131). 
W ten sposób część socjologii obecnie przechodzi od fazy dyscyplinarnej (choć dyscyplinarność nadal broni się poprzez instytucjonalną obronę grup interesu, zarówno profesjonalnych jak i organizacyjnych) poprzez fazę interdyscyplinarnych badań do fazy transdycyplinarnej, gdy w coraz mniejszym stopniu reguły i zasady refleksyjności zaledwie jednej dyscypliny odgrywają jakąś rolę w badaniach i analizach naukowych. Koncentracja tematyczna (na problemie, na temacie, na kwestii), a nie definiowana teorią pochodzącą z jednej dyscypliny, odgrywa coraz większa rolę. Choć należy podkreślić, że dyscypliny nie znikną szybko ze względu na strukturalne uwarunkowania badań naukowych, reguł ich finansowania i zarządzania oraz kontroli wiedzy naukowej. Wiedza ta jest „dyscyplinowana" za pomocą niezwykle do tego celu użytecznych dyscyplin naukowych.

Próbowaliśmy sprawdzić, m.in., w jakim stadium jest obecnie nauka społeczna uprawiana $w$ instytutach socjologicznych w polskich wyższych szkołach publicznych ${ }^{6}$. Do tego celu posłużyła nam ankieta wysłana do 17 instytutów socjologii działających w uczelniach publicznych (uzyskano do analizy 16 ankiet). Wskaźnikami pojawienia się postdyscyplinarnych trendów było dla nas użycie następujących metod i technik badawczych i analitycznych: metod performatywnych, analiz rytuałów/demonstracji/parad/festiwali, autoetnografii, etnografii performatywnej, autoetnografii, metod badań i analiz wizualnych (jak np. wizualna teoria ugruntowana), metod analiz dźwięków, metod analiz zapachów, metod analizy dyskursu. Metody te skupiają się na badaniach lub analizach wybranych wcześniej tematów/problemów bez zdecydowanej prekonceptualizacji badawczej i teorii wywodzących się z jednej dyscypliny naukowej. Użycie tych metod powoduje, iż świat socjologii ma porowate granice i może przyjmować, wchłaniać, modyfikować różne koncepcje teoretyczne i metodologiczne z innych dyscyplin. Dyscypliny te także, stosując identyczne metody, są otwarte na idee innych dyscyplin lub idee spoza dyscyplin naukowych, np. ze świata sztuki. Ponadto ważnym wskaźnikiem postdyscyplinarności były badania o charakterze aplikacyjnym, gdzie często diagnozujący rzeczywistość badacz jest jednocześnie zanurzony w zmianę badanej rzeczywistości i korzysta z różnych teoretycznych i praktycznych inspiracji by rozwiązać jakiś „,realny” problem społeczny.

\footnotetext{
${ }^{6}$ Badanie kierunków zainteresowań teoretycznych $\boldsymbol{i}$ badawczych $w$ Instytutach Socjologii w Polsce przeprowadzono wiosną 2013 r. Posłużyło ono głównie diagnozie stanu socjologii jakościowej i częstości używania metod oraz technik badan jakościowych stosowanych i nauczanych obecnie w socjologii polskiej w uczelniach publicznych. Były również pytania dotyczące używanych w badaniach i rozwijanych teorii. Na pytania krótkiej ankiety odpowiadali wybrani eksperci z danego Instytutu, znający jego realia badawcze, uprawiane i rozwijane teorie oraz stosowane metody i techniki badawcze.
} 
Natomiast teorie wskazujące na zwrot ku postdyscyplinarności przyjęliśmy następujące ${ }^{7}$ :

- teorie feministyczne i gender (4),

- Actor Network Theory (3),

- teoria zrównoważonego rozwoju (2),

- antropologia zmysłów (1),

- eklektyzm teoretyczny (1),

- ,teoria żywej kultu” (1),

- teorie queer (1),

- teorie cielesności (1).

Częstość stosowania tych teorii nie skłaniają nas do konkluzji, że w polskich instytutach socjologicznych występuje zwrot performatywny lub tendencja ku postdyscyplinarności. Tezę tę zdają się potwierdzać dane dotyczące stosowanych metod. Tylko analizy dyskursu i analizy wizualne były stosowane dosyć często, obydwie metody w dziewięciu instytutach każda. Nie podkreślano idei aplikowalności badań ani epistemologii i teorii znoszących dualizm podmiotu i przedmiotu badania. Zwrot performatywny nadal może być co najwyżej, w 2013 r., postulatem w polskiej socjologii, nie faktem.

Należy jednak podkreślić, że różnorodne metody jakościowe są stosowane prawie we wszystkich ośrodkach, zarówno metody badawcze, jak i metody analizy danych (często stosowana jest metodologia teorii ugruntowanej i analizy dyskursu). One to mogą przyczynić się do rozprzestrzeniania się idei transdycyplinarności a nawet postdyscyplinarności ${ }^{8}$.

Idee postdyscyplinarności spotykają się także z krytyką na gruncie socjologii. Niektórzy socjologowie twierdzą, że: „Szczególnie negatywnym aspektem postdyscyplinarności jest epistemologiczny eklektyzm połączony z narracją nie podporządkowaną żadnym rygorom i regułom" (Kojder 2012: 15). Inni socjologowie próbują poprzez dialog wewnątrz dyscypliny, a także pomiędzy

${ }^{7} \mathrm{~W}$ nawiasach są częstotliwości występowania tych teorii w badanych instytutach, w sumie wymieniono 41 razy stosowanie różnych teorii, 14 z nich wskazują na postdyscyplinarne odniesienia.

${ }^{8}$ Szczególnie interesująca jest tutaj inicjatywa społeczna Transdycyplinarnego Seminarium Badań Jakościowych. Ta międzydyscyplinarna inicjatywa łączy, integruje, a także sprzyja dialogowi pomiędzy różnymi dyscyplinami, np. socjologią, pedagogiką, zarządzaniem, architekturą, sztuką, psychiatrią, neurofizjologią itp. Corocznie odbywają się konferencje oraz warsztaty, które cieszą się dużym zainteresowaniem badaczy jakościowych, na pewno tworzących już w tej chwili ważne środowisko badań transdycyplinarnych w Polsce. Do tej pory odbyły się dwa sympozja, jedno w Kazimierzu Dolnym, a drugie w Łodzi (zob. http://www.tsbj-lodz.pl/pl.historia.html; http:// www.tsbj-lodz.pl/pl.materialy.html). 
dyscyplinami, oraz rekonceptualizację podstawowych pojęć stworzyć płaszczyznę do analizy i krytyki idei pozwalając ciągle zachować ważność i integralność dyscypliny socjologii $\mathrm{w}$ zmieniającym się postdycyplinarnym świecie (Camic, Joas 2004: 14-16). Ci ostatni autorzy mówią o zwrocie dialogicznym, który wy-stępuje we fragmentarycznej rzeczywistości współczesnych teorii socjologicz-nych, niemogących już stworzyć wielkiej syntezy. Obecną fazą rozwoju nauk społecznych i humanistycznych wydaje się być dialog pomiędzy dyscyplinami oraz wielość głosów odnośnie do analiz określonych problemów. Dialog ten może odbywać się na forach transdycyplinarnej debaty, jak np. dzieje się to w przypadku Transdycyplinarnego Seminarium Badań Jakościowych.

\section{Bibliografia}

Afeltowicz Ł., Pietrowicz K. (2013), Maszyny spoteczne. Wszystko ujdzie o ile działa, Wydawnictwo Naukowe PWN, Warszawa.

Anderson L. (2006), Analytic autoethnography, ,Journal of Contemporary Ethnography”, vol. 35, no. 4.

Baert P. (2003), Pragmatism, Realism and Hermeneutics, [w:] Foundations of Science, 8. Kluwer Academic Publishers, Printed in the Netherlands.

Baert P. (2005), Towards a Pragmatist-Inspired Philosophy of Social Science, „Acta Sociologica”, vol. 48, no. 3. DOI: 10.1177/0001699305056562.

Becker H.S. (1982), Art Worlds. Berkeley, University of California Press.

Bendyk E. (2013), Homo eroticus. Socjolog Michel Maffesoli o kryzysie naszej cywilizacji i o tym, co będzie po nim, Wywiad z Michaelem Maffesolim, „Polityka”, 09.04.13, http://www. polityka.pl/nauka/czlowiek/1540037,1,spoleczenstwo-narod-czym-sa-dzisiaj-te-pojecia.read \#ixzz2WND4BEmM (16.06.2013).

Camic Ch., Joas H. (ed.) (2004), The Dialogical Turn: New Roles for Sociology in the Postdyscyplinary Age, Rowman \& Littlefield, Lanham.

Charmaz K. (2009), Teoria ugruntowana. Praktyczny przewodnik po analizie jakościowej, Wydawnictwo Naukowe PWN, Warszawa.

Clarke A.E. (1991), social worlds/arenas theory as organizational theory, [w:] D.R. Maines (ed.), Social Organization and Social Process. Essays in Honor of Anselm Strauss, Aldine de Gruyter, New York.

Dijk van T.A. (1998), Principles of Critical Discourse Analysis, [w:] J. Cheshire, P. Trudgill (eds), The Sociolinguistics Reader, vol. 2: Gender and Discourse, Arnold, London.

Domańska E. (2007), „Zwrot performatywny” we wspótczesnej humanistyce, „Teksty Drugie”, nr 5. 
Domańska I. (2011), Antropologia Literatury - projekt interdyscyplinarny czy transdycyplinarny, „Przegląd Kulturoznawczy”, vol. 1(9), http:www.staff.amu.edu.pl/ ewa/Domanska,\%20 Zwrot\%20performatywny\%20we\%20wspolczesnej\%20humanistyce.pdf (15.04.2013).

Duszak A., Fairclough N. (2008), Krytyczna analiza dyskursu. Interdyscyplinarne podejście do komunikacji społecznej, Universitas, Kraków.

Ellis C., Adams T.\&Bochner A.P. (2010), Autoethnography: An overview [40 paragraphs], „Forum Qualitative Sozialforschung/Forum: Qualitative Social Research”, no. 12(1), Art. 10, http:// nbn-resolving.de/urn:nbn:de:0114-fqs1101108 (16.06.2013).

Fleck L. (1935/1986), Powstanie i rozwój faktu naukowego: wprowadzenie do nauki o stylu myślowym i kolektywie myślowym, Wydawnictwo Lubelskie, Lublin.

Foucault M. (2003), Society Must Be Defended: Lectures at the Collège de France 1975-1976, Picador, New York.

Gibbons M., Limoges C., Nowotny H., Schwartzman S., Scott P., Trow M. (1994), The New Production of Knowledge: The Dynamics of Science and Research in Contemporary Societies, Sage, London.

Glaser B., Strauss A. (2009), Odkrywanie Teorii Ugruntowanej. Strategie badania jakościowego, Nomos, Kraków.

Kacperczyk A. (2005), Zastosowanie koncepcji spotecznych światów w badaniach empirycznych, [w:] E. Hałas, K.T. Konecki (red.), Konstruowanie jaźni i spoteczeństwa. Europejskie warianty interakcjonizmu symbolicznego, Scholar, Warszawa.

Kacperczyk A. (2012), Badacz i jego ciało w procesie zbierania i analizowania danych - na przyktadzie badań nad społecznym światem wspinaczki, „Przegląd Socjologii Jakościowej”, t. 8, nr 2, http://www.przegladsocjologiijakosciowej.org (16.06.2013).

Kita M., Sławska M. (2012), Transdyscyplinarność badań nad komunikacją medialna, Wydawnictwo Uniwersytetu Śląskiego, Katowice.

Kojder A. (2012), „Postdyscyplinarność w socjologii”, [w:] J. Zamecka (red.), Normy, dewiacje, $i$ kontrola społeczna, t. XIII, Uniwersytet Warszawski, IPSiR, Warszawa.

Konecki K.T. (2000), Studia z metodologii badań jakościowych. Teoria ugruntowana, Wydawnictwo Naukowe PWN, Warszawa.

Krzewińska A. (2012), Sądy obywatelskie - kilka refleksji o metodzie, „Folia Sociologica”, nr 42.

Merton R. (1965), On the Shoulders of Giants, Harcourt Brace Jovanovich, New York.

Nowotny H. (2006), The potential of Transdyciplinarity by Helga Nowotny, http://helganowotny.eu/downloads/helga_nowotny_b59.pdf (01.06.2013).

Nowotny H., Scott P., Gibbons M. (2003), Rethinking Science - Knowledge and the Public in an Age of Uncertainty, Polity Press, Cambridge. 
Nyström P. (2007), La interdisciplinariedad y la transdisciplinariedad en la organización del conocimiento científico: Interdisciplinarity and transdisciplinarity in the organization of scientific knowledge, [w:] Actas del VIII Congreso ISKO - España, León, 18, 19 y 20 de Abril de 2007, http://dialnet.unirioja.es/descarga/articulo/2532824.pdf (13.04.2013).

Olechnicki K. (2003), Antropologia obrazu. Fotografia jako metoda, przedmiot i medium nauk spotecznych, Oficyna Naukowa, Warszawa.

Pink S. (2003), Interdyscyplinary agendas in visual research: re-situating visual anthropology, „Visual Studies”, vol. 18, no. 2.

Rancew-Sikora D. (2013), Dyskurs i interakcja - problem trafnego wyboru kontekstu do interpretacji rozmów, „Przegląd Socjologii Jakościowej”, t. 9, nr 1, www.przegladsocjologiijakos ciowej.org (16.06.2013).

Rapley T. (2007), Doing Conversation, Discourse and Document Analysis, Sage, L.A.

Rorty R. (1982). Consequences of Pragmatism, University of Minnesota Press, Minneapolis.

Rorty R. (1999), Philosophy and the Social Hope, Penquin Books, London.

Siarkiewicz E., Trębińska-Szumigraj E., Zielińska-Pękal D. (2012), Edukacyjne prowokacje wykorzystanie etnografii performatywnej w procesie kształcenia doradców. Impuls, Kraków.

Star S.L., Griesmer J.R. (1989), Institutional Ecology, "translations" and boundary objects: amateurs and professionals in Berkeley museum of verterbrate zoology, 1907-1939, „Social Studies of Science", no. 19.

Strauss A. (1978), A social world perspective, [w:] N. Denzin (ed.), Studies in Symbolic Interaction, vol. 1, Greenwich, CT, JAI Press.

Strauss A. (1982), Social world and legitimation processes, [w:] Studies in Symbolic Interaction, vol. 4, Greenwich, CT, JAI Press.

Stubbe M., Chris L., Jo H., Elaine V., Bernadette V., Meredith M., Janet H., Weatherall A. (2013), Interakcja w miejscu pracy z perspektywy kilku podejść dyskursywnych, „Przegląd Socjologii Jakościowej”, t. 9, nr 1, www.przegladsocjologii jakosciowej.org (16.06.2013).

Sztompka P. (2005), Socjologia wizualna. Fotografia jako metoda badawcza, Wydawnictwo Naukowe PWN, Warszawa.

Sztompka P. (2012), Dziesięć tez o socjologii, „Nauka”, nr 4.

Wall S. (2008), Easier Said than done. Writing an autoethnography, „International Journal of Qualitative Methods", vol. 7, no. 1.

Wodak R., Krzyżanowski M. (2008), Qualitative Discourse Analysis in the Social Sciences, Palgrave, New York. 


\section{Podziękowania}

Autorzy chcieliby uprzejmie podziękować Pani dr Agnieszce Golczyńskiej-Grondas za życzliwe komentarze i konsultacje oraz za udostępnienie nie publikowanego jeszcze tekstu Biographical research and treatment. Some remarks on therapeutic aspects of sociological biographical interview.

Autorzy dziękują także wszystkim Osobom, które wysłuchawszy referatu $O d$ relacji badacz - respondent do relacji psychoterapeuta - pacjent. Wybrane problemy etyczne wywiadów biograficznych podczas konferencji Społeczeństwo, edukacja, gospodarka. W stulecie urodzin profesora Jana Szczepańskiego w kwietniu 2013 r., były uprzejme podzielić się w dyskusji swoimi refleksjami i komentarzami. Pozwoliło to na bardziej precyzyjne sformułowanie wielu tez artykułu. 